\title{
A new analytical system, based on an acoustic wave sensor, for halitosis evaluation
}

\author{
Daniel L.A. Fernandes ${ }^{a}$, Tony A. Rolo ${ }^{b}$, João A.B.P. Oliveira ${ }^{a}$, M. Teresa S.R. Gomes ${ }^{a, *}$ \\ a CESAM E' Department of Chemistry, University of Aveiro, 3810-193 Aveiro, Portugal \\ b Department of Dentistry, Faculty of Medicine, University of Coimbra, 3049-075 Coimbra, Portugal
}

\section{A R T I C L E I N F O}

\section{Article history:}

Received 22 May 2008

Received in revised form 15 October 2008

Accepted 23 October 2008

Available online 5 November 2008

\section{Keywords:}

Acoustic wave sensor

Halitosis

Hydrogen sulphide

\begin{abstract}
A B S T R A C T
A new inexpensive analytical system to analyze $\mathrm{H}_{2} \mathrm{~S}$ in the exhaled breath is presented. The system is based on an acoustic wave sensor, employing a piezoelectric quartz crystal with a chemical coating sensitive to the analyte (triethanolamine). The paper addresses the choice of the quartz crystal coating and of the adsorbent used in the preconcentration column, as well as the optimization of the crystal cell design, oscillator and frequency counter. It includes also an extensive study on possible interferences and on its elimination. The analytical system composed of the $\mathrm{H}_{2} \mathrm{~S}$ sensor, the preconcentration column and water absorbents, allowed the injection of sample volumes of $400 \mathrm{~mL}$, which made possible to reaching detection limits of $50 \mathrm{ppb}(\mathrm{v} / \mathrm{v})$. This low detection limit, allied to a sensitivity of $85.6 \mathrm{~Hz} / \mathrm{ppm}$, was effective in discriminating healthy individuals from patients with periodontal disease. $\mathrm{H}_{2} \mathrm{~S}$ levels from $170 \mathrm{ppb}(\mathrm{v} / \mathrm{v}$ ) to $1625 \mathrm{ppm}(\mathrm{v} / \mathrm{v})$ were found in breath samples. All healthy individuals showed levels of $\mathrm{H}_{2} \mathrm{~S}$ lower than $255 \mathrm{ppb}(\mathrm{v} / \mathrm{v})$. Patients known to suffer to some kind of gum pathology presented a wide range of $\mathrm{H}_{2} \mathrm{~S}$ concentrations in the exhaled air, which could only be explained after more extensive clinical evaluation. (c) 2008 Elsevier B.V. All rights reserved.
\end{abstract}

\section{Introduction}

Bad breath is a condition that affects a large number of persons, with implications in their social life. Halitosis is the general term used to describe any unpleasant odour in the exhaled air, independently of the odoriferous substances and of their source, which can be oral or extra-oral. Its occurrence can be a consequence of a health disturbance, which increases the importance of its detection and evaluation $[1,2]$.

Halitosis is difficult to assess by the individuals and a simple non-subjective methodology is needed [2].

The development of an analytical methodology starts with the knowledge, as complete as possible, of the sample. The inhaled air is approximately composed of $78 \%$ of nitrogen, $21 \%$ of oxygen, $0.96 \%$ of argon and $0.04 \%$ of carbon dioxide, helium, water, and other gases, while in the exhaled air oxygen level ranges from $15 \%$ to $18 \%$, carbon dioxide is presented in amounts from $4 \%$ to $5 \%$, and water vapour is around $\approx 5 \%$. Moreover, other compounds, some with malodour, can also be found, in tiny amounts, in the expired air. Among them are sulphur compounds, which are characteristic of periodontal diseases, like gingivitis and periodontitis, amine compounds, which

\footnotetext{
* Corresponding author.

E-mail address: mtgomes@ua.pt (M.T.S.R. Gomes).
}

can be associated with hepatic or kidney failure, and acetone, that may be present in severe diabetics. Some of these compounds can be sensed by human nose in concentrations of a few parts per million (ppm) or parts per billion (ppb) [2-5]. External agents like tobacco, alcohol, garlic, and spices can be sources of bad breath, and mask the presence of compounds with pathologic origin [2].

Fig. 1 shows some of the compounds responsible for bad breath associated with possible pathogenic sources. Among those compounds, hydrogen sulphide possesses a very pungent odour and it is extremely important as a marker for mouth pathologies. Its malodour can be sensed by human nose in concentrations as small as $250 \mathrm{ppb}(\mathrm{v} / \mathrm{v})$ [1]. The analytical detection of this compound in such low concentrations is very difficult and organoleptical examination by a panel of trained judges is still the reference standard, although variability between judges is expected. Instrumental methodologies demand specific and expensive equipment such as a gas chromatograph (GC) with a flame photometric or sulphur chemilumenescent detector $[1,2]$. Not so expensive instruments called Halimeters have been developed to measure sulphur gases. Although these devices measure the total volatile sulphur compounds in breath, they detect them with different sensitivities and are sensitive to other compounds that can interfere in the analysis, such as water vapour and others present in mouthrinses, alcoholic beverages and smoke. In spite of the fact that Halimeter and GC measurements positively correlate, GC continues to be the method of choice, whenever accurate and precise results are required $[2,6]$. 


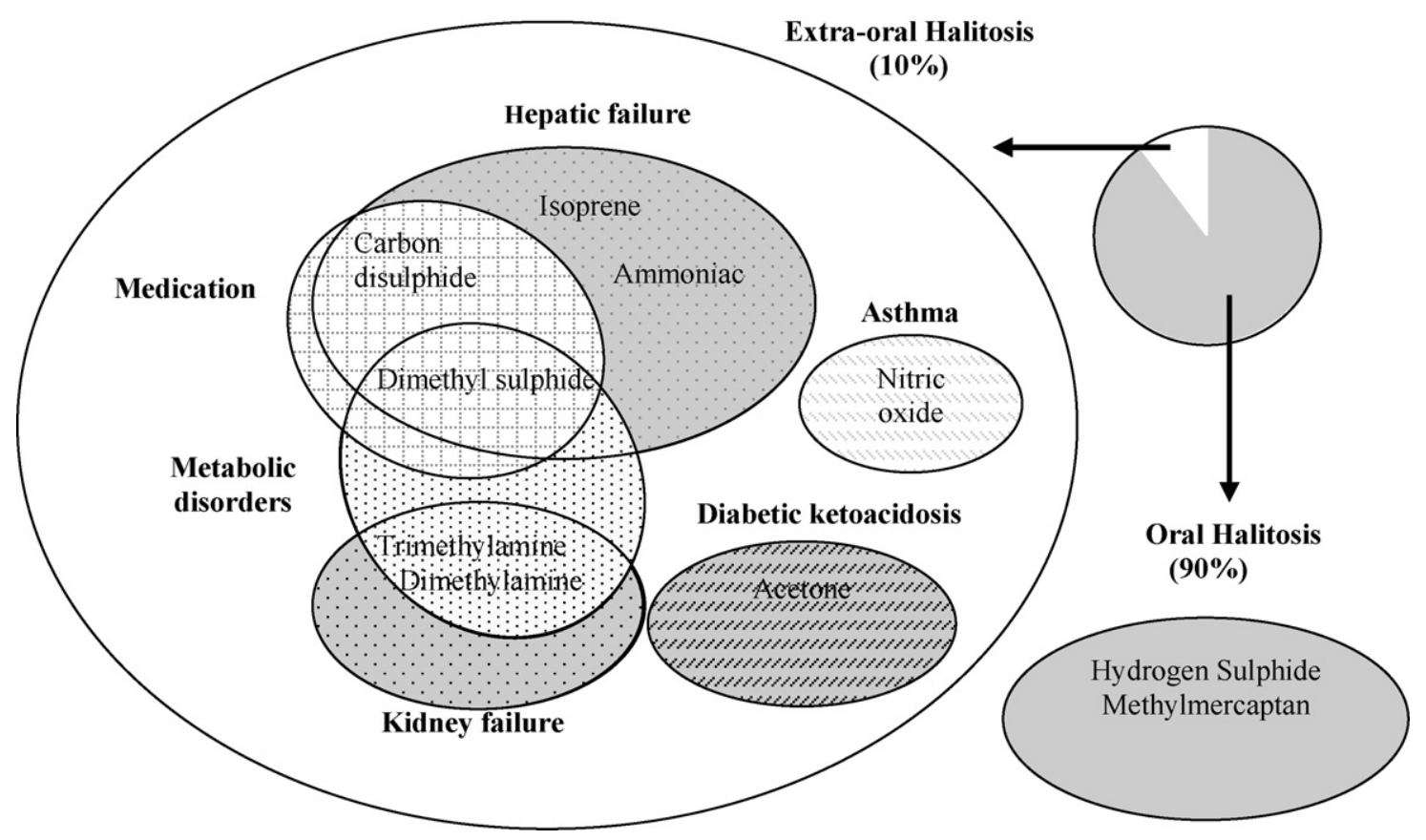

Fig. 1. Some of the most important compounds responsible for halitosis and their origin.

The aim of this work was to develop an analytical system based on piezoelectric quartz crystals, for the quantification of hydrogen sulphide in breath, and to use it in the detection of halitosis and periodontal diseases at the very early stages. The new system is basically composed of a preconcentration column and an acoustic wave sensor for hydrogen sulphide. These bulk acoustic wave sensors are inexpensive, as all it is needed is a piezoelectric material, usually quartz, widely used in electronics, an oscillator and a frequencymeter. Cost can be slightly increased if an acquisition data system is used, which is dispensable in the present work.

In order to detect $\mathrm{H}_{2} \mathrm{~S}$, a sensitive layer must be applied onto the quartz crystal electrodes. This sensitive layer must be carefully chosen, as it must be very stable and selective to the compound to be detected. The analytical signal will be generated by the interaction of the target analyte, hydrogen sulphide, and the coating layer. This coating determines not only the sensitivity to hydrogen sulphide but also the selectivity of the sensing device.

In general, these sensors are not sensitive enough or selective to analyze $\mathrm{H}_{2} \mathrm{~S}$ in real samples. As the detection limit for hydrogen sulphide needs to be very low, it was necessary to incorporate a preconcentration unit in the analytical system. Several methods have already been used to concentrate some gaseous compound from breath samples: sorbent trapping, cold trapping, condensate trapping and chemical trapping $[7,8]$. Both sorbent trapping and cold trapping were tried to concentrate $\mathrm{H}_{2} \mathrm{~S}$. Besides being used to lower $\mathrm{H}_{2} \mathrm{~S}$ detection limits, the preconcentration column could also be effective in trapping possible interfering compounds, and this aspect was also considered. Compounds ordinarily used as adsorbents in preconcentration columns are polymers, resins or molecular sieves. Several compounds were tested as adsorbents in the preconcentration column and their ability to concentrate the $\mathrm{H}_{2} \mathrm{~S}$ and to reject $\mathrm{CO}_{2}$ and $\mathrm{H}_{2} \mathrm{O}$ was evaluated.

A complete report of the main steps of the development, and the final arrangement of the analytical system are here reported, along with the results of the analyses of the breath of patients clinically evaluated in what concerns to periodontal diseases. The analytical system is mostly homemade and considerably cheaper than the Halimeter. The most expensive piece of equipment, the acquisition system, could be replaced by a specially designed less expensive one, as many of the functionalities of the PXI-6608 were not used.

\section{Experimental}

\subsection{Reagents}

Eight quartz crystals were coated, each with a different compound. Coating compounds were: triethanolamine (TEA, Merck 8377), poly-vinylidene fluoride (Kynar, Fluka 81432), Nafion 117 solution (Nafion, Fluka 70160), manganese(II) phthalocyanine (Mn_pht, Aldrich 379557), poly(dimethylsiloxane) (PDMS, ABCR 76189), Tenax TA 80/100 (Tenax, Supelco 21009), tetramethylammonium fluoride tetrahydrate (TMAF, Aldrich 10,721-2), magnesium(II) phthalocyanine (Mg_pht, Aldrich 40,273-7), 1,4polyisoprene (Fluka 81445) and mercapto hexanol (Fluka 63762).

Nitrogen, used as a carrier, was Alphagaz from ArLíquido. Ethanol (Merck 100983), propanone (Lab-Scan A3501), isoprene (Riedel-de Haën 62791), carbon disulphide (Panreac 141244), pentane (Lab-Scan C2518), trimethylamine (TMA, Merck 821177), ammoniac (Aldrich 29,499-3), dimethyl sulphide (Aldrich M8,1632), ethanethiol (Fluka 04290), carbon dioxide (N45, ArLíquido), nitric oxide $5083 \mathrm{ppm}$ in $\mathrm{N}_{2}$ (Praxair 10102-43-9), nitrogen dioxide $5011 \mathrm{ppm}$ in $\mathrm{N}_{2}$ (Praxair 10102-44-0), and carbon monoxide, generated from formic acid (Panreac 131030) and sulphuric acid (Fluka 84720), were used to test sensor selectivity.

Standards were prepared in teflon bags (Cole-Parmer U143070), and samples were collected in Tedlar bags $1 \mathrm{~L}$ (SKC 231-01).

Calcium chloride anhydrous (Absolve 50075), ammonium nitrate (Riedel-de Haën 11218) and Nafion membranes (Omnifit) were used to dry the samples.

Molecular sieves 5A (Fisher scientific company M-521), activated carbon (Merck 3626719), Tenax TA (Supelco 21009) and molecular sieve ETS-4 (synthesized) were tested as sorbents.

Sodium sulphide (Panreac 211682) and sulphuric acid (Fluka 84720 ) were used to generate $\mathrm{H}_{2} \mathrm{~S}$, and potassium iodate (Pan- 


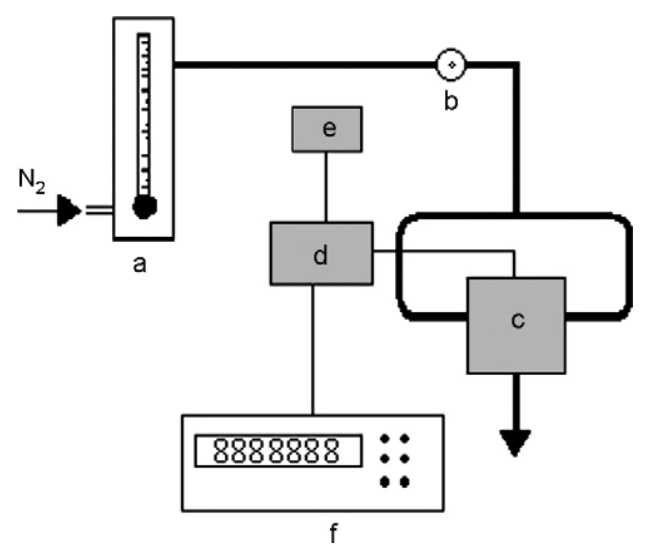

Fig. 2. Instrumental setup used to evaluate coated quartz crystal sensitivity and selectivity to $\mathrm{H}_{2} \mathrm{~S}$ : (a) flowmeter, (b) injection port, (c) quartz crystal cell, (d) oscillator, (e) power supply and (f) frequencymeter.

reac 141540), potassium iodide (Panreac 121542), iodine (M\&B MU6609), sodium thiosulphate (Merck 5269604), and sodium hydroxide (Panreac 131687) were used to standardize the generated gas.

\subsection{Apparatus}

A spin coater (Süss Delta $10 \mathrm{BM}$ ) and an air brush (BADGER model 200) were used to coat the quartz crystals. The quartz crystals were $9 \mathrm{MHz}$ AT-cut HC45 with gold electrodes (Euroquartz).

Fig. 2 shows the experimental layout used to study the sensitivity and selectivity of the different sensors. The developed system is a flow injection analyzer. A constant stream of nitrogen, controlled by a flowmeter, is continuously flowing through the cell that houses the coated piezoelectric quartz crystal. An injection port allows the introduction of the sample, oscillator was assembled according to Bruckenstein and Shay design [9], and the frequency was obtained through a frequencymeter (Leader LF-827).

Fig. 3 shows the experimental layout used in the exhaled air analysis. Starting from the experimental arrangement displayed in Fig. 2, the analytical system was optimized by reducing the size of the sensor cell and minimizing the dimension of the Teflon tubes, both in diameter and in length, in order to reduce dispersion and increase the analytical signal. Oscillator was home-made, and was based on the Bruckenstein and Shay design [9], to which an extra CMOS divider device (74HC292) was added. A data acquisition unit,

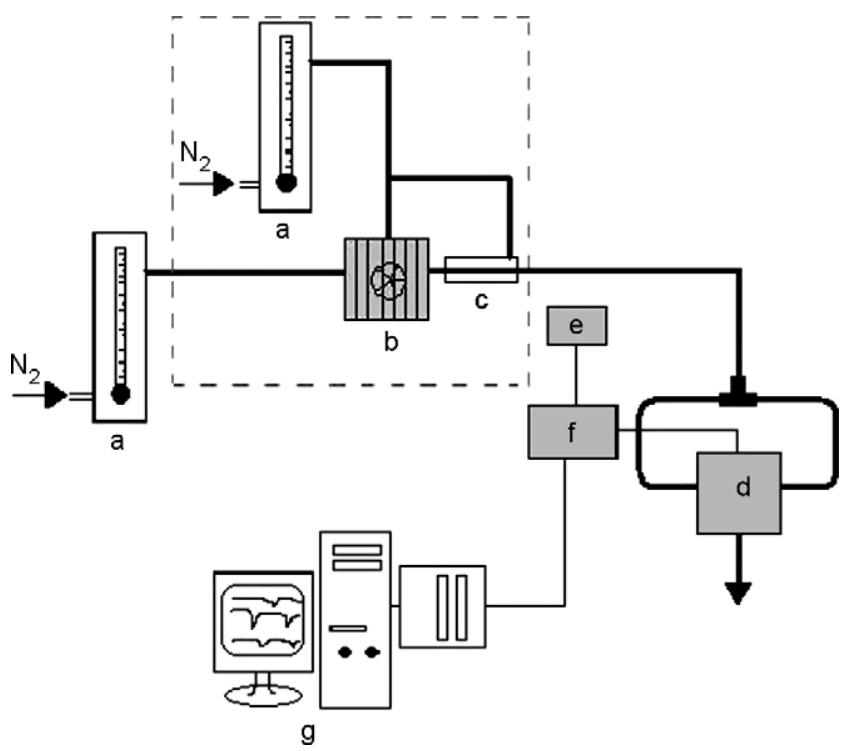

Fig. 3. Layout of the system used to analyze $\mathrm{H}_{2} \mathrm{~S}$ in the exhaled air: (a) flowmeter, (b) injection and preconcentration unit, (c) Nafion membrane, (d) quartz crystal cell, (e) power supply, (f) oscillator and (g) counter/timer PXI-6608 and computer.

a Counter/Timer PXI 6608 (National Instruments) and a PC were used. The CMOS device coupled to the oscillator circuit board is programmable and can divide the frequency from $2^{2}$ to $2^{31}$. The divider was programmed to generate a signal with a frequency that is $2^{-20}$ times the one of the original signal, and the internal time base of the PXI $6608(80 \mathrm{MHz})$ was used to count this signal. This way, $2^{20}$ cycles of the original signal were counted with, at most, an uncertainty of 1 cycle of the time base, while, without the divider, the uncertainty would be one cycle of the time base per cycle of the original signal. making possible to decrease the counting error. A LabView program was specially written to count and store frequencies. The modified oscillators, combined with acquisition board and the written software allowed increasing the resolution of the frequency reading, which was monitored with an uncertainty of $0.1 \mathrm{~Hz}$, against the $1 \mathrm{~Hz}$ achieved with the ordinary frequencymeters for acquisition times as short as $1 \mathrm{~s}$ [10]. A preconcentration unit was also added to the initial analytical system.

Fig. 4 shows the two crystal cells used in this work. Initially, to study the sensitivity and selectivity to $\mathrm{H}_{2} \mathrm{~S}$ of the different sensors, with the experimental setup of Fig. 2, a glass cell (Fig. 4a), with a $15 \mathrm{~mL}$ volume was used. This cell was later modified, and
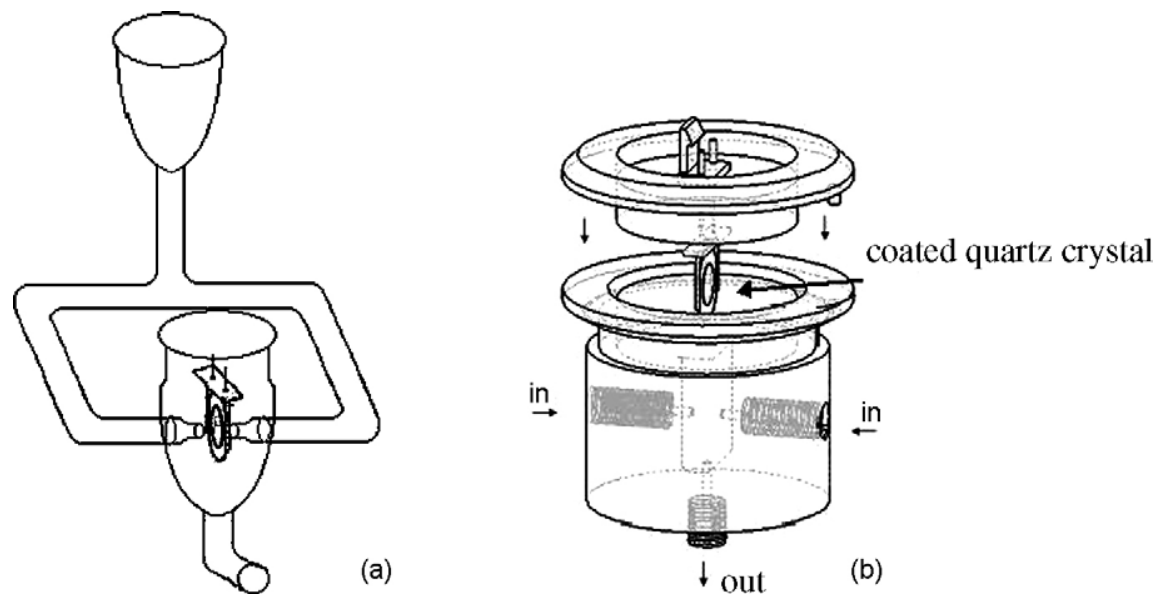

Fig. 4. Quartz crystal cells: (a) glass cell with the volume of $15 \mathrm{~mL}$ and (b) PVC cell with the volume of $0.35 \mathrm{~mL}$. 

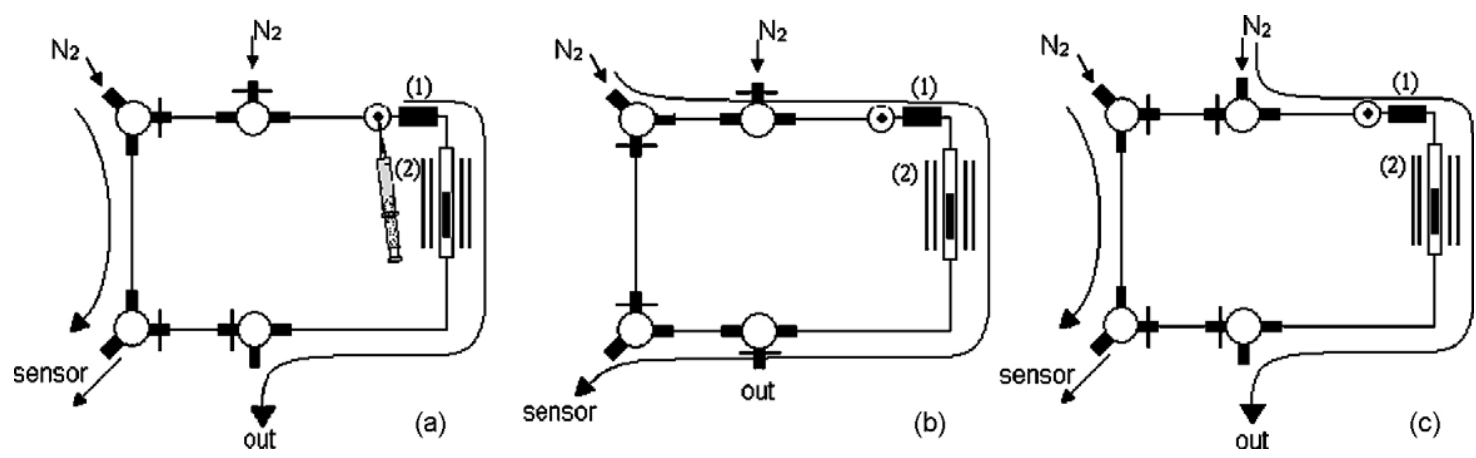

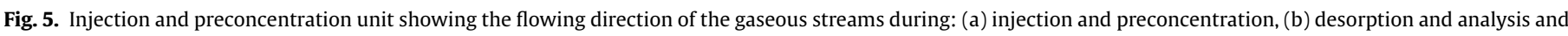
(c) column regeneration. (1) Calcium chloride anhydrous column and (2) heating coil/Peltier device.

the volume decreased to $0.35 \mathrm{~mL}$ (Fig. $4 \mathrm{~b}$ ). The volume reduction increased the sensitivity which was mandatory in order to analyze the breath samples. This latter cell was used in all the analysis, performed with the experimental setup of Fig. 3. Both cells possess two inputs, directed towards the crystal faces, and one output at the bottom. Before entering the crystal cell, the nitrogen stream was divided and directed to both entrances.

Fig. 5 shows, in detail, the injection and preconcentration unit. A tube filled with calcium chloride, was placed before the preconcentration column, with the purpose of drying the sample, without adsorbing any of the sulphur volatiles [11].

Fig. 6 shows the sampling system, which consisted of a Tedlar bag with a septum and a valve. The bag was coupled through the valve to a inox-U-shaped tube immersed in a cooling mixture ammonium nitrate:water $1: 1$, which maintain the temperature at $-2{ }^{\circ} \mathrm{C}$. This tube efficiently removes most of the water vapour by condensation. The tube was connected to a replaceable polyethylene tube.

A Nafion membrane, shown in Fig. 3, was introduced, between the preconcentration column and the sensor, to dry the water not trapped in the calcium chloride tube. An external $\mathrm{N}_{2}$ stream, flowing at sample counterflow, increased the drying efficiency of the membrane.

\subsection{Procedure}

\subsubsection{Coating the quartz crystal}

Each quartz crystal was coated by spraying, spin coating, or dropping the coating solution onto the crystal electrodes. The compounds tested as coating were: polyisoprene, Nafion, Mg_pht, Kynar, Tenax, PDMS, TEA, mercapto hexanol, Mn_pht and TMAF.

\subsubsection{Sensor sensitivity and selectivity}

The sensors were tested by injecting different quantities of $\mathrm{H}_{2} \mathrm{~S}$ into the system shown in Fig. 2.

For each sensor, a calibration curve was obtained and the $\mathrm{H}_{2} \mathrm{~S}$ detection limit was determined as the analyte concentration giv-

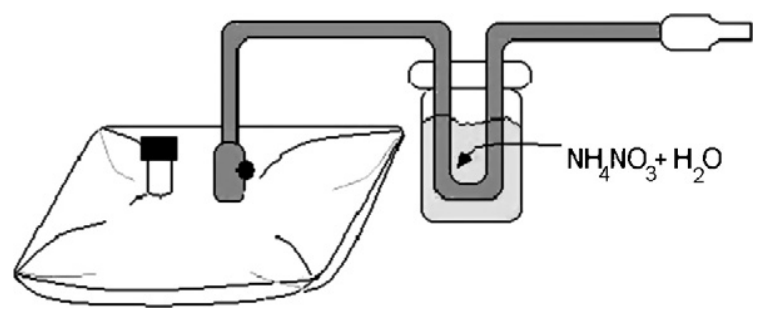

Fig. 6. Sampling apparatus. ing a signal $y_{\mathrm{B}}+3 s_{\mathrm{B}}$, where $y_{\mathrm{B}}$ is the blank signal, estimated from the intercept, and $s_{B}$ is the standard deviation of the blank, estimated from the standard error of the estimate $s_{y / x}$. The most sensitive sensor to $\mathrm{H}_{2} \mathrm{~S}$ was selected to be used afterwards in breath analysis.

Then, for the selected sensor, new detection limits have been obtained using the new PVC cell (Fig. 4b) and setup shown in Fig. 3.

\subsubsection{Preparation of $\mathrm{H}_{2} \mathrm{~S}$ standards}

$\mathrm{H}_{2}$ S gas was generated adding $50 \%(\mathrm{v} / \mathrm{v})$ sulphuric acid to sodium sulphide.

$10 \mathrm{~mL}$ of the generated $\mathrm{H}_{2} \mathrm{~S}$ were injected into a $1 \mathrm{~L}$ Teflon bag, which was then filled with $\mathrm{N}_{2}$. Final concentration was close to $10,000 \mathrm{ppm}$. The content of the bag was later standardized, using aliquots of $30.0 \mathrm{~mL}$ of the inner gas, which was trapped in an $0.02 \mathrm{M}$ $\mathrm{NaOH}$ solution into a flask with a septum. The trapped $\mathrm{H}_{2} \mathrm{~S}$ was iodometrically titrated [12]. Lower concentration standards, in the range from $162 \mathrm{ppb}(\mathrm{v} / \mathrm{v})$ to $1.08 \mathrm{ppm}(\mathrm{v} / \mathrm{v})$, were obtained by further diluting with $\mathrm{N}_{2}$. These standards were used to obtain the calibration curves.

\subsubsection{Preparation of the preconcentration columns}

Preconcentration columns were prepared by packing a glass tube with $20 \mathrm{~cm}$ length, $8 \mathrm{~mm}$ o.d. and $2.2 \mathrm{~mm}$ i.d., with $2-3 \mathrm{~cm}$ of adsorbent and sealing it with plugs of silanized glass wool. Adsorbents tested were Tenax TA (80-100 mesh), ETS-4, activated carbon, and MS-5A. Activated carbon and MS-5A columns were conditioned prior to use, by heating at $250^{\circ} \mathrm{C}$ for at least $6 \mathrm{~h}$, with $\mathrm{N}_{2}$ as carrier gas. Tenax and ETS- 4 columns were conditioned at $200^{\circ} \mathrm{C}$.

\subsubsection{Selection of the patients and behaviour protocol}

Patients were volunteers recruited among the ones attending the practice at the University of Coimbra Dental School. Patients were requested to abstain from eating, drinking or smoking before evaluation. These recommendations followed others reported in the literature [13-15].

\subsubsection{Sampling}

The patients needed to blow through a disposable and individual mouthpiece of polyethylene until the $1 \mathrm{~L}$ bag becomes partially full. Filling the bag requires no effort from the patients, as tubes are wide, i.d. $0.5 \mathrm{~cm}$, and without restrictions.

\subsubsection{Analysis}

Samples were collected from patients and were always analyzed on the same day they were collected, in order to avoid losses or contaminations. New calibration curves were prepared each day. The preconcentration column was conditioned at $250^{\circ} \mathrm{C}$ prior to 
the injection of each sample or standard. The drying calcium chloride tube was changed every day, in order to avoid $\mathrm{H}_{2} \mathrm{~S}$ losses by dissolution into the water trapped inside the tube.

Initially the preconcentration column was refrigerated to $5-8^{\circ} \mathrm{C}$ with an air stream cooled by a Peltier device. $400 \mathrm{~mL}$ of sample were then injected through the injection port and $\mathrm{H}_{2} \mathrm{~S}$ was preconcentrated in the column (Fig. 5a). Meanwhile, a constant stream of $\mathrm{N}_{2}$ was passing through the crystal cell. Then, four 3-port switching valves were used to redirect the carrier gas and force it to pass through the adsorption column for desorption of $\mathrm{H}_{2} \mathrm{~S}$ from sample. Desorption of the sample compounds trapped on the adsorbent column was accomplished by switching on the electrical heating wire which surrounded the column (Fig. 5b). Temperature was $250^{\circ} \mathrm{C}$ inside the column.

Frequency of the quartz crystal was stored in a PC, at intervals of $1 \mathrm{~s}$, along all the analytical steps. After heating, $\mathrm{H}_{2} \mathrm{~S}$ was released from the column and adsorbed onto the crystal coating, producing a frequency decrease. Later on, frequency began to increase, indicating that the response to $\mathrm{H}_{2} \mathrm{~S}$ has finished, and that the sensor was recovering. Then, the four 3-port switching valves were used to redirect the carrier gas to the alternative way, in order to prevent water from reaching the sensor while column was regenerating (Fig. 5c).

The analytical signal was the difference between the original frequency of the quartz, observed before column heating, and the lowest frequency, observed after $\mathrm{H}_{2} \mathrm{~S}$ desorption from the column.

\section{Results and discussion}

Table 1 shows the detection limits obtained with the different coated quartz crystals. These results have been obtained with the experimental setup shown in Fig. 2. The sensors coated with TEA and TMAF showed the lowest detection limit $\left(3 \mu \mathrm{g}\right.$ of $\mathrm{H}_{2} \mathrm{~S}$ ) and the highest sensitivity $(1.19 \mathrm{~Hz} / \mu \mathrm{g}$ for the TMAF sensor and $1.00 \mathrm{~Hz} / \mu \mathrm{g}$ for the TEA sensor), although the coating amounts were lower than the ones applied on the other sensors. Coating amounts for TEA and TMAF produced a similar frequency decrease ( $13 \mathrm{kHz}$ ).

TEA sensor was finally selected because the TMAF signal is much more complex. At room temperature, the $\mathrm{H}_{2} \mathrm{~S}$ absorption on TMAF can lead to a sudden frequency rise, explained by the liquefaction of the absorption product, and slight temperature changes can affect the frequency signal [16].

As breath is a complex mixture of compounds, the TEA sensor was tested concerning possible interferences from the other compounds known to be present in the breath. Fig. 7 shows the selectivity coefficients for a series of compounds. The selectivity coefficients $(\mathrm{K})$ are here defined as the ratio between the amounts of tested compound and $\mathrm{H}_{2} \mathrm{~S}$ that produced a $15 \mathrm{~Hz}$ signal. As it can be seen, selectivity coefficients near 1 were only found for $\mathrm{NH}_{3}$ and TMA. However, the sensor responded much more to $\mathrm{NO}$ and $\mathrm{NO}_{2}$ than to $\mathrm{H}_{2} \mathrm{~S}$.

Table 1

Detection limits for $\mathrm{H}_{2} \mathrm{~S}$ obtained with the several coatings.

\begin{tabular}{lc}
\hline & Detection limit $\left(\mu \mathrm{H} \mathrm{H}_{2} \mathrm{~S}\right)$ \\
\hline Polyisoprene & 284 \\
Nafion & 731 \\
Mg_pht & 812 \\
Kynar & 417 \\
Tenax & 62 \\
PDMS & 739 \\
TEA & 3 \\
Mercapto hexanol & 1525 \\
Mn_pht & 350 \\
TMAF & 3 \\
\hline
\end{tabular}

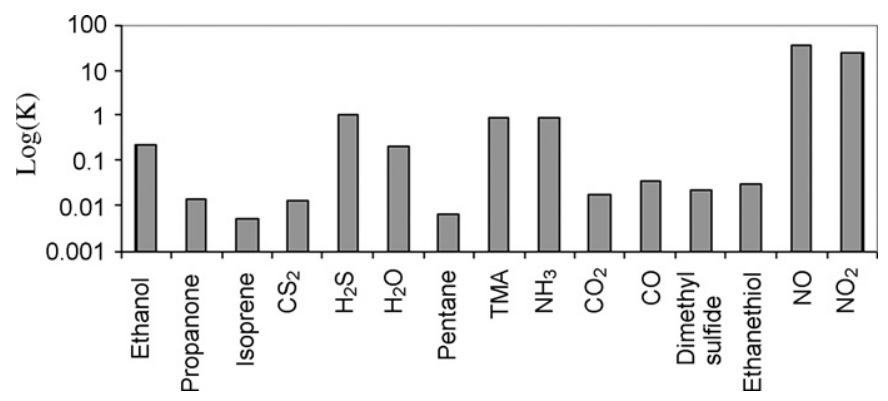

Fig. 7. Selectivity coefficients of the $\mathrm{H}_{2} \mathrm{~S}$ sensors regarding some possible interferents.

The detection limit of $3 \mu \mathrm{g}$ of $\mathrm{H}_{2} \mathrm{~S}$ was insufficient to detect $\mathrm{H}_{2} \mathrm{~S}$ in breath samples, and it was not possible to reduce it significantly just by increasing the coating amount. Thus, as it was already said, starting from the setup shown in Fig. 2, a smaller sensor cell was assembled, in the setup shown in Fig. 3. Moreover, the diameter and length of tubes were diminished, and the Bruckenstein oscillator and the frequencymeter were replaced by a new set oscillator/frequency counter, capable of frequency measurements with $0.1 \mathrm{~Hz}$ uncertainty [10]. Sensitivity improved from $1.00 \mathrm{~Hz} / \mu \mathrm{g}$ $\left(\Delta F_{\text {due to coating }}=13.7 \mathrm{kHz}\right)$ to $8.14 \mathrm{~Hz} / \mu \mathrm{g}\left(\Delta F_{\text {due to coating }}=11.3 \mathrm{kHz}\right)$ and detection limit improved to $27 \mathrm{ng}$. These changes succeeded in increasing de sensitivity and in decreasing the detection limit of the new system. The detection limit was 100 times smaller than the one obtained with the older system, due to a 10 times increase in sensitivity and a 10 times increase in the frequency precision.

However, even with these changes, the $\mathrm{H}_{2} \mathrm{~S}$ analysis in breath samples remained impossible. The new system was limited to injections of sample volumes as large as $2.5 \mathrm{~mL}$, which, with a detection limit of $27 \mathrm{ng}\left(20 \mathrm{~nL}\right.$ of $\mathrm{H}_{2} \mathrm{~S}$ ), only allows the detection of concentrations above $8 \mathrm{ppm}(\mathrm{v} / \mathrm{v})$ of $\mathrm{H}_{2} \mathrm{~S}$.

To solve this problem a preconcentration column was introduced. Four different compounds were tested as sorbent compound on the column: Tenax, MS-5A, ETS-4 and activated carbon.

The preconcentration column should release the sorbed $\mathrm{H}_{2} \mathrm{~S}$ when heated. If the heat of the column reaches the sensors, the frequency of the coated quartz crystals can be highly affected, as well as their ability to respond to $\mathrm{H}_{2} \mathrm{~S}$. Although the sensors are physically far way from the column, and therefore, presumably, their temperature is not affected during column heating, tests have been performed to confirm this assumption. The frequencies of the quartz crystals have been monitored while the column heating coil was turned on and off and no effect has been recorded on the frequency of the sensors.

Tenax was reported [11] to be a good $\mathrm{H}_{2} \mathrm{~S}$ trap, but needs very low temperatures (liquid nitrogen). This proved to be a problem for breath samples due to their high water and carbon dioxide content. Besides, $\mathrm{H}_{2} \mathrm{~S}$ is desorbed from Tenax at room temperatures, which causes $\mathrm{H}_{2} \mathrm{~S}$ losses in the process of inserting the cold column into the analytical system. The MS-5A compound is a more selective sorbent than Tenax, and was also reported to be a good trap for $\mathrm{H}_{2} \mathrm{~S}$ [17] at room temperature. However, this trap proved to be more selective to water than to $\mathrm{H}_{2} \mathrm{~S}$, with the additional problem of adsorbing carbon dioxide, which is, along with water, one of the compounds present at the highest concentration.

Fig. 8 shows a plot of the frequency $v$ s. time of the TEA sensor, when two standards have been injected in the system which included a molecular sieve MS-5A column. The black line represents the frequency of the sensor obtained injecting a standard of $\mathrm{H}_{2} \mathrm{~S}$ and $\mathrm{H}_{2} \mathrm{O}$, and the gray line represents the frequency of the sensor when a standard with the three compounds, $\mathrm{H}_{2} \mathrm{~S}, \mathrm{CO}_{2}$ and $\mathrm{H}_{2} \mathrm{O}$, was injected. As can be seen, the sample with $\mathrm{H}_{2} \mathrm{~S}$ and $\mathrm{H}_{2} \mathrm{O}$ 


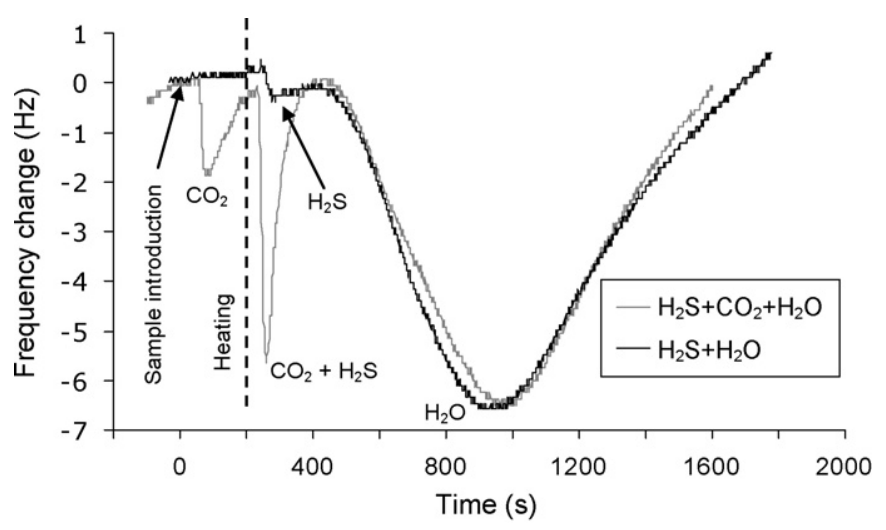

Fig. 8. Frequency of the sensor, coupled to a MS-5A column, after injection of a standard containing $\mathrm{H}_{2} \mathrm{~S}$ and water (black line) and a standard with $\mathrm{H}_{2} \mathrm{~S}, \mathrm{CO}_{2}$ and water vapour (gray line).

produced two signals after column heating, at 1 and $4 \mathrm{~min}$, respectively. In the case of the sample with the three compounds $\left(\mathrm{H}_{2} \mathrm{~S}\right.$, $\mathrm{CO}_{2}$, and $\mathrm{H}_{2} \mathrm{O}$ ), the results were different. The $\mathrm{CO}_{2}$ shows two signals: one before and another one after column heating. The second signal of $\mathrm{CO}_{2}$ occurs at the same time as the $\mathrm{H}_{2} \mathrm{~S}$ signal, becoming impossible to distinguish them. Therefore, the use of MS-5A as a sorbent in the preconcentration column is not recommended for the $\mathrm{H}_{2} \mathrm{~S}$ analysis in breath samples.

The ETS- 4 is a titanosilicate molecular sieve, and seamed to be a good candidate to $\mathrm{H}_{2} \mathrm{~S}$ sorbent, due to the compatibility of pore size and to its poor affinity to carbon dioxide. However, it was found that the $\mathrm{H}_{2} \mathrm{~S}$ reacted with ETS-4, making impossible its quantification.

Finally, activated carbon was tested as an $\mathrm{H}_{2} \mathrm{~S}$ sorbent. Activated carbon possesses also poor affinity to carbon dioxide, which is a clear advantage. At this point, it was decided to eliminate water vapour from breath samples introducing several traps (shown in Figs. 3, 5 and 6). First, water was pre-trapped by condensation during the breath sampling, into a refrigerated inox-U-shaped tube. A tube with calcium chloride was inserted before the preconcentration column, and a Nafion membrane after it, to reduce the water vapour concentration in the sorbent.

Fig. 9 shows the frequency of the sensor obtained in the system with a preconcentration column with activated carbon, injecting a standard with three compounds $\left(\mathrm{H}_{2} \mathrm{~S}, \mathrm{CO}_{2}\right.$ and $\left.\mathrm{H}_{2} \mathrm{O}\right)$. As can be seen, the $\mathrm{CO}_{2}$ is not retained on the activated carbon col-

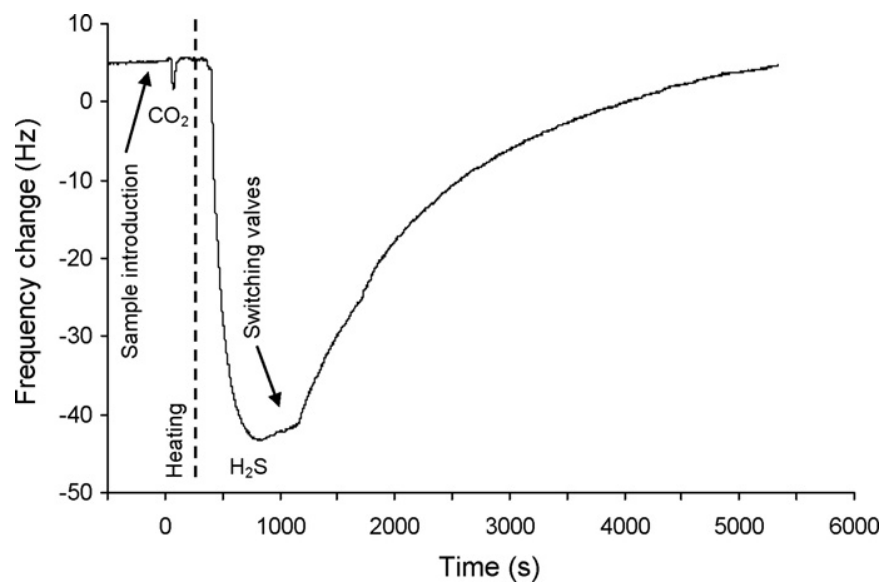

Fig. 9. Frequency of the sensor, coupled to an activated carbon column and with a Nafion membrane as drying, after injection of a standard containing $\mathrm{H}_{2} \mathrm{~S}, \mathrm{CO}_{2}$ and water vapour. umn and its signal appears before column heating. Therefore, no interference due to $\mathrm{CO}_{2}$ was observed at the time of the $\mathrm{H}_{2} \mathrm{~S}$ signal elution. The change of slope observed after the beginning of the $\mathrm{H}_{2} \mathrm{~S}$ desorption from the crystal coating can be explained by the valves switching. No water vapour signal could be observed, which proves that water was successfully eliminated by the Nafion membrane and the calcium chloride anhydrous tube. Besides, experiments with standards with equal amounts of $\mathrm{H}_{2} \mathrm{~S}$ and different water vapour quantities have shown to produce equal $\mathrm{H}_{2} \mathrm{~S}$ signals.

With the preconcentration column it was possible to inject large quantities of the sample, which allows the analysis of low concentrations of $\mathrm{H}_{2} \mathrm{~S}$. Linear calibration curves in the range from $162 \mathrm{ppb}$ $(\mathrm{v} / \mathrm{v})$ to $1.08 \mathrm{ppm}(\mathrm{v} / \mathrm{v})$ were successfully obtained injecting $400 \mathrm{~mL}$ of standards. Sensitivity was $85.6 \mathrm{~Hz} / \mathrm{ppm}$ and detection limit was $50 \mathrm{ppb}(\mathrm{v} / \mathrm{v})$, which corresponds to a mass of $28 \mathrm{ng}$ of $\mathrm{H}_{2} \mathrm{~S}$, very similar to the detection limit reported without preconcentration, as expected.

As the sensor responds to $\mathrm{NH}_{3}$, TMA, $\mathrm{NO}$ and $\mathrm{NO}_{2}$, these compounds were injected into the system, in the highest possible concentration found in human breath, in order to find out if they could be a problem in the $\mathrm{H}_{2} \mathrm{~S}$ analysis. Neither, $\mathrm{NH}_{3}$, TMA, NO or $\mathrm{NO}_{2}$ did affect the analysis of $\mathrm{H}_{2} \mathrm{~S}$, when present in quantities lower than $250 \mathrm{ppm}(\mathrm{v} / \mathrm{v})$ of $\mathrm{NH}_{3}, 3.5 \mu \mathrm{g} / \mathrm{L}$ of TMA, $25 \mathrm{ppm}(\mathrm{v} / \mathrm{v})$ of $\mathrm{NO}$ and $25 \mathrm{ppm}(\mathrm{v} / \mathrm{v})$ of $\mathrm{NO}_{2}$. Therefore, incorporation of the adsorption column proved to be quite effective in concentrating $\mathrm{H}_{2} \mathrm{~S}$ and in eliminating, or decreasing, $\mathrm{CO}_{2}, \mathrm{NH}_{3}$, TMA, $\mathrm{NO}$ and $\mathrm{NO}_{2}$ interference.

Table 2 shows the results of the analysis of the exhaled breath of patients along with their medical record.

Table 2

Results of the analysis of the exhaled breath samples along with the dental clinica evaluation of the patients.

\begin{tabular}{|c|c|c|}
\hline Clinical evaluation & $\begin{array}{l}\mathrm{H}_{2} \mathrm{~S} \text { concentration } \\
(\mathrm{ppb})\end{array}$ & $\begin{array}{l}\text { Under } \\
\text { treatment }\end{array}$ \\
\hline $\begin{array}{l}\text { Localized moderate chronic } \\
\text { periodontitis }\end{array}$ & 1625 & Yes \\
\hline $\begin{array}{l}\text { Generalized severe chronic } \\
\text { periodontitis }\end{array}$ & 888 & No \\
\hline $\begin{array}{l}\text { Generalized severe chronic } \\
\text { periodontitis }\end{array}$ & 789 & No \\
\hline Severe gingivitis & 709 & No \\
\hline $\begin{array}{l}\text { Localized moderate chronic } \\
\text { periodontitis }\end{array}$ & 576 & Yes \\
\hline $\begin{array}{l}\text { Generalized severe chronic } \\
\text { periodontitis }\end{array}$ & 539 & No \\
\hline $\begin{array}{l}\text { Generalized moderate } \\
\text { chronic periodontitis }\end{array}$ & 502 & Yes \\
\hline $\begin{array}{l}\text { Generalized moderate } \\
\text { chronic periodontitis }\end{array}$ & 435 & Yes \\
\hline $\begin{array}{l}\text { Localized moderate chronic } \\
\text { periodontitis }\end{array}$ & 373 & No \\
\hline $\begin{array}{l}\text { Generalized severe chronic } \\
\text { periodontitis }\end{array}$ & 337 & Yes \\
\hline $\begin{array}{l}\text { Generalized severe chronic } \\
\text { periodontitis }\end{array}$ & 299 & No \\
\hline Moderate gingivitis & 283 & Yes \\
\hline Mild Gingivitis & 259 & No \\
\hline $\begin{array}{l}\text { Localized moderate chronic } \\
\text { periodontitis }\end{array}$ & 252 & Yes \\
\hline $\begin{array}{l}\text { Generalized severe chronic } \\
\text { periodontitis }\end{array}$ & 170 & No \\
\hline Healthy individual & 255 & No \\
\hline Healthy individual & 249 & No \\
\hline Healthy individual & 243 & No \\
\hline Healthy individual & 212 & No \\
\hline Healthy individual & 201 & No \\
\hline
\end{tabular}

a Smoker which did not obey the protocol. 
As can be seen, there are significant differences between signals of healthy individuals and patients with periodontal diseases. Comparing the means of the two groups by the $t$-test $(P=0.05)$ it can be concluded that the mean concentration of the $\mathrm{H}_{2} \mathrm{~S}$ of patients with periodontal diseases is statistically higher than the mean concentration of $\mathrm{H}_{2} \mathrm{~S}$ in healthy individuals.

Healthy individuals showed $\mathrm{H}_{2} \mathrm{~S}$ contents as high as $255 \mathrm{ppb}$ ( $250 \mathrm{ppb}$ is referred as the limit which divides healthy from sick people [1]). The patients with periodontal diseases showed values well above the ones from the healthy patients, with the exception of two patients with periodontal diseases, one of them with a localized moderate chronic periodontitis submitted to an ongoing periodontal treatment, and the other one was a smoker which did not follow the established rules, and that has smoked just before sample collection.

The $\mathrm{H}_{2} \mathrm{~S}$ concentration in patients with periodontal diseases ranged from 252 to $1625 \mathrm{ppb}(\mathrm{v} / \mathrm{v})$ and the values cannot be explained by the clinical evaluation reported in Table 2 , which was restricted to gum disorders. Other investigators [18-20] did also not found a correlation between the severity of the periodontal disease and the prevalence or severity of halitosis. Bacterial plaque in teeth, tonsils and tongue has not been reported for these patients, and may be responsible for halitosis in some extension. Besides, the exhaled air has both oral and pulmonary origin and although $90 \%$ of all bad breath odours emanate from mouth, the upper and lower respiratory tracks, the gastrointestinal track, and some diseases from the kidney or the liver cannot be excluded. Diet of patients, especially if rich in proteins, may also influence their breath.

This new analytical methodology may be used as a quick but accurate screaming test for breath malodour, which is a clear indication of some health problem that should be investigated.

\section{Acknowledgements}

This project was founded by the University of Aveiro, and CESAM. One of the authors, D. Fernandes, wishes to thanks the Portuguese Foundation for Science and Technology for financial support.

\section{References}

[1] J. Rodrígues, R. Pereiro, A. Sanz-Medel, Determination of volatile sulphur compounds in mouth air, Spectroscopy-Europe 14 (2002) 6-14.

[2] A. Tangerman, Halitosis in medicine: a review, Int. Dent. J. 52 (2002) 201-206.

[3] A. Amann, A. Schmid, S. Scholl-Burgi, S. Telser, H. Hinterhuber, Breath analysis for medical diagnosis and therapeutic monitoring, Spectroscopy-Europe 17 (2005) 18-20.

[4] P. Ratcliff, P. Johnson, The relationship between oral malodor, giingivitis, and periodontitis: a review, J. Periodontol. 70 (1999) 485-489.
[5] K. Yaegaki, K. Sanada, Biochemical and clinical factors influencing oral malodour in periodontal patients, J. Periodontol. 63 (1992) 783-789.

[6] J. Furne, G. Majerus, P. Lenton, J. Springfield, D. Levitt, M. Levitt, Comparison of volatile sulphur compounds concentrations measured with a sulphide detector vs. gas chromatography, J. Dent. Res. 81 (2002) 140-143.

[7] M. Phillips, Detection of volatile organic compounds in breath, in: N. Marczin, S. Kharitonov, M. Yacoub, P. Barnes (Eds.), Disease Markers in Exhaled Breath, 170, Marcel Dekker, New York, 2002, pp. 219-231.

[8] M. Phillips, Method for the collection and assay of volatile organic compounds in breath, Anal. Biochem. 247 (1997) 272-278.

[9] S. Bruckenstein, M. Shay, Experimental aspects of use of the quartz crystal microbalance in solution, Electrochim. Acta 30 (1985) 1295-1300.

[10] D.L.A. Fernandes, J.A.B.P. Oliveira, M.T.S.R. Gomes, Detecting spoiled fruit in the house of the future, Anal. Chim. Acta 617 (2008) 171-176.

[11] A. Tangerman, Determination of volatile sulphur compounds in air at the parts per trillion level by Tenax trapping and gas chromatography, J. Chromatogr. 366 (1986) 205-216.

[12] G.H. Jeffery, J. Bassett, J. Mendham, R.C. Denney. Análise Química Quantitativa-Vogel. Guanabara Koogan, Rio de Janeiro, Brasil, 1992.

[13] M. Sanz, S. Roldán, D. Herrera, Fundamentals of breath malodour, J. Contemp. Dent. Pract. 4 (2001) 1-17.

[14] K. Yaegaki, J.M. Coil, Examination, classification, and treatment of halitosis; clinical perspectives, J. Can. Dent. Assoc. 66 (2000) 257-261.

[15] S.S. Lee, W. Zhang, Y. Li, Halitosis update: a review of causes, diagnoses, and treatments, CDA J. 55 (2007) 259-268.

[16] M.T.S.R. Gomes, P.S.T. Nogueira, J.A.B.P. Oliveira, Quantification of $\mathrm{CO}_{2}, \mathrm{SO}_{2}, \mathrm{NH}_{3}$ and $\mathrm{H}_{2} \mathrm{~S}$ with a single coated piezoelectric quartz crystal, Sens. Actuators B 68 (2000) 218-222.

[17] M. Black, R. Herbst, D. Hitchcock, Solid adsorbent preconcentration and gas chromatographic analysis of sulfur gases, Anal. Chem. 50 (1978) 848-851.

[18] A. Bosy, G.V. Kulkarni, M. Rosenberg, C.A. McCulloch, Relationship of oral malodour to periodontitis: evidence of independence in discrete subpopulations, J. Periodontol. 65 (1994) 37-46.

[19] M. Morita, H.L. Wang, Relationship between sulcular sulfide level and oral malodor in subjects with periodontal disease, J. Periodontol. 72 (2001) 79-84.

[20] L.C. Figueiredo, E.P. Rosetti, E. Marcantonio, R.A.C. Marcantonio, S.L. Salvador, The relationship of oral malodor in patients with or without periodontal disease, J. Periodontol. 73 (2002) 1338-1342.

\section{Biographies}

Daniel A.L. Fernandes has recently received $\mathrm{PhD}$ in chemistry from the University of Aveiro. He received a degree in Biochemistry in 2002 also from the University of Aveiro. His current research interests are in chemical sensors, biochemistry and biotechnology.

Tony A. Rolo is a guest assistant of Periodontology at the Department of Dentistry of the Faculty of Medicine of the University of Coimbra. He received his degree in Dentistry from the University of Coimbra in 1999. His current research interests are in Lasers in Periodontology and Oral Surgery.

João A.B.P. Oliveira is an associate professor at the University of Aveiro. He received his degree in chemical engineering from the Technical University of Lisbon in 1976 and a PhD in Analytical Chemistry from the University of Virginia in 1985. His current research interests are chemical sensors and chemometrics.

M. Teresa S. R. Gomes is an associate professor at the University of Aveiro. She received her degree in chemical engineering from the University of Coimbra in 1983 and a PhD in Analytical Chemistry from the University of Aveiro in 1997. Her current interests are chemical sensors and analytical chemistry. 